\title{
Aspects of Word Formation in Official Bulletin of Albanian Government in 1925
}

\author{
Dr. Suela Kastrati \\ Faculty of Education, \\ "Aleksandër Moisiu" University, Durrës
}

\section{Doi:10.5901/mjss.2014.v5n27p1791}

Abstract

This study aims to analyze the language of "Official Bulletin of 1925" of the Albanian government, to reflect the important features of word-structure of the Albanian language in that period, with a view to point out the ways and means of wordformation which were active in this field and their specifications. The study of grammatical structure of the formative in the context of specific parts of the speech is necessary, not only to know, to understand better the structure of the Albanian language and to clarify a number of theoretical problems according to different ways of word-formation, the difference between prefixes borders, compound and the composition, but also to reflect the language development and to its wordformation system in a certain period of time, such as that of 1925, at which time the Albanian language was still unconsolidated. For this study has been considered a relatively large literature that includes the whole range of our authors, Dictionary of Contemporary Albanian language (1980), Spelling Dictionary (1976) Terminological glossary, Dictionary of Albanian Language (1954). It is also consulting and exploiting "The formation of affix names in Albanian "Prof. Enver Hysa, K. Cipo's Albanian grammar etc.

Keywords: word-formation, structure, suffix, prefix, compound, composition etc.

\section{Introduction}

The study of grammatical structure of the formative in the context of specific parts of the speech is necessary, not only to know, to understand better the structure of the Albanian language and to clarify a number of theoretical problems according to different ways of word-formation, the difference between prefixes borders, compound and the composition, but also to reflect the language development and to its word-formation system in a certain period of time, such as that of 1925, at which time the Albanian language was still unconsolidated.

As Hysa (2004) states, "... problems of word formation have begun to attract the attention of researchers very late". Generally, researchers as Dh. Kamarda, A. Dozoni, G. Vajgand, I. Dilo Sheperi , O. Myderrizi, etc., have continuously worked with word-formation, but as M. Domi notes, "the first study of the formation of words in Albanian language, after a few notes of K. Kristoforidhi is the deep study of prof. dr. A. Xhuvani" (Hysa 2004)

Since the goal of this paper is the study of word-structures and their features, a considerable space in this paper will take the study of words formed by two highly productive ways in Albanian language, with affixes (prefixes the suffixes), with composition or superimposition.

As has been noted by numerous researchers, the eagle has great possibilities of forming words from derivatives as her own words. The albanian language has a great zest for ways of forming words, leading to the creation of new lexical synthetic units.

\section{Aspects of word formation in Official Bulletin of 1925}

As it is known, the formation of words with affixes is divided into two types: using prefixes and suffixes. They both are very productive ways in Albanian language.

The following words are formed using prefixes, which modify their meaning but do not change the class of the words. Below are found the formations with prefixes, as: e paratregueme - betoken (p.6, No.31), e paluajtshme immovable (p.8, No. 22), e sipër-përmendur - the above-mentioned (p.7, no. 22), të paditur - accused (p.7, No. 22), të pa dënuem - non convicted (p.1, No. 22), i përzim - mixed (p.1, No. 22 ), të përkundërt - the reverse (p.1, 17), përmbledhje summary (f.12, no.20), për-ndryshe - otherwise (p.8, No. 30), përgënjeshtron - retorts (p.7, No.31), paravepru - proceed, rikonstaton - reascertain (p.7, No.31), riemërohet - renominate (p.6, No. 22), pa aftësi - inability (p.3, No. 22), e sipërtregueme (p.7, No.31), shlirimin - release (p.11, No.23), çpallje - proclamation (p.8, No. 22), nënprefektura - sub- 
prefecture (p.7, No. 22), etc., belong to different classes of grammar as adjectives, verbs, nouns, adverbs.

Word formation with prefixes, although it is a special type, it is associated with blending and composing, without having clear-cut boundaries between them (Hysa 2004). Historically it is known that a number of prefixes come from prepositions, which are attached with the word and have become a grammatical tool for forming new words.

Some of the most important elements that stay in front of the words are: para-, pa-, sipër-, për-, ri-, sh-, ç-, nën-, etc. Depending on their grammatical meaning these elements can be:

1. Words which are used as adverbs and prepositions as well, for example para, sipër, which are usually used as adverbs;

2. Words used only as prepositions, such as: pa-, nën.

3. A separate group which is constituted by elements as: për-, ri-, sh-, ç-, which serve only as prefixes.

Elements of first and second group are considered to be non-simple words. Certainly these words formed by these means, in Albanian linguistics literature, are sometimes viewed in the context of superimposition. Cipo (1949) states that: "The etymology of the word helps us to understand that the prefix is put on top of the word by changing its first meaning". Thus, adjectives such as e tregueme (dialect) - told, e luajtshme - movable; e përmendur - well known; të ditur acquainted; të dënuem (dialect) - condemned; të bame (dialect) - done; i zim (dialect.) - boiled; të kundërt - opposite; are attached with the prefixes para, pa, sipër and have formed superimposed adjectives e paratregueme, e paluajtshme, e sipër-përmendur, të paditur, të padënuem, të përbame, i përzim, të përkundërt which do not quite have the meaning of simple adjectives; even to some adjectives as e sipër-përmendur,të pa dënuem, e sipër-tregueme, the process of synthesize is not yet completed, which marks a particular trend in Albanian language. Even the past participle of the verb veproj - act, vepruar - acted, which here are used in dialect, vepru, is attached with prefix para- which immediately changes its first meaning. Similarly even from the words konstaton - ascertain, emërohet - nominate, are formed superimposed verbs rikonstaton and riemërohet through the attachment of the prefix ri-; these verbs are enriched with new meanings.

Albanian language has quite such formations where the proposition is transformed into prefix, but surely the point of departure of these formations is exactly superimposition which has returned these prepositional elements into prefixes.

The prefix para- (pre) in the harvested material mainly joins with the infinitive of the verb or with the past participle, which often comes in the dialectical form: tregueme (told), vepru (acted), etc.

In Ofiicial Bulletin of 1925 are identified noun formations with one of the most productive elements of Albanian language, which is bashke - co prefix. In the word bashkëzotnoni (co-own) this prefix is merged with the verb zotnoj, which is a theme derived from word zot, zoteroj (own-owner). The verb here is in Gegh dialect and it is in the second form, plural, present tense (you own). Even in this formation, the element bashke- co retains its adverbial value. Of course, such types of words are seen as intermediate types, where the boundary between composition and affixation is quite portable. In such cases, we tend to study this type under prefix formations and not formatted under the composition model. So it is further explained the free connection of these units as separate words. Of interest is to note that the formations with the prefix co-, are not popular in folk language; they are constructs of the language of culture.

Another type of words often found in this document, are nouns formed with the prefix nën- sub such as: nënprefektura (p.7, No.22), nënëkrys ( $\mathrm{p} .-4$, No.31), nënështetas ( $\mathrm{p}$. , No.31), nëpunës ( $\mathrm{p} .4$, No.22), nëpunësina ( $p .18$, No.20), where the prefix nën-,, once is found in its old form nënë-, and sometimes reduced in the form of në-. This prefix, as well as the opposite prefix $\mathrm{mbi}$, is shown over-productive and vibrant. Here, this prefix is merged with:

- Simple nouns: krysi (dialect.), etc.

- Other derived nouns: prefektura, shtetas, punësina,, etc.

In all these nouns, the prefix nën- in semantic terms has the meaning of addiction or subdivision, i.e: nënprefektura is a small unit under prefecture jurisdiction.

Even the proposition për-, was adjacent to different words that belong to the class of nouns, adjectives, verbs, adverbs, etc., as: përmbledhje-12-20, të përbame-1-22, i përzim-1-22, të përkundërt-1-17, përgënjeshtron-7-31, përndryshe-8-30, etc. On the other hand productive are the formations with prefixes and suffixes, such as e përgjithshme-722, të përvjetshme-2-22, të përkohëshme-4-22, etc.

A special place among the words used in the Official Bulletin are formations with the prefix pa- without, with denying meaning, such as e paluajtshme- immovable, 8-22, të paditur - sued7-22, të pa dënuem- not convicted 1-22, të pa tundëshëm-1-22, e paudhëshme-1-1, pa aftësi-disability 3-22, etc.; some of these formations have not completed the process of synthesize, hence the prefix is separated by the word, as të pa dënuem-1-22,të pa tundëshëm-1-22, etc. From the semantic point of view nouns and adjectives formed with the prefix pa- without, show the lack of the meaning which is expressed by the word-topic or exclude it, for example: aftësi-pa aftësi, të ditur-të paditur, etc.

Similar meaning with the prefix pa- is the prefix mos-, which in Albanian languages primarily operates as a 
negative prefix. As such it serves to oppose or fully deny the action expressed by the verb. The word mosvonim (p.3, No. 22), which is evidenced in the Official Bulletin, is formed with the prefix mos-, which indicates that this formative has lost connection with the words to which it stands, where it performs the function of the particle, ie: mos vono(im). As can be easily seen, although it is in front of the verb as a particle, when it becomes formative element, it does not form a verb but a noun. So, at least since 1925, we can say with conviction that in our standard language, there are no cases, where the prefix mos- is used to form verbs, being placed before a verb.

Prefix formations are also some forms of verbal forms as past participle, gerund form, infinitive, such as: çkallmuarstave in, (p.8-20), tue paramenduar-7-31, me shnatyruem-1-23. Even these forms reinforce the opinion expressed above, which highlight the idea that Albanian language has not been standardized yet at the time when this document was written, but it still has obvious influences from the old form of northern dialect. In today's Albanian standard, the past participle çkallmuar is written shkallmuar, meanwhile the infinitive of Gheg me shnatyruem is written with the prefix de-, which is a foreign suffix that has a limited use in Albanian language. Gerundive and infinitive form of dialect verbs, respectively: tue paramenduar, me shnatyruem - to transfigure, today in standard Albanian are found in the form: duke paramenduar and për të denatyruar.

One of the ways of enriching Albanian vocabulary is through suffixes which are productive not only in the field of names, but also in the field of adjectives, verbs and adverbs.

A large number of names are formed in Albanian language with the suffix - (e)si. According to A. Xhuvani and E. Çabej: "This suffix is an extension of action nouns which end in -es with -i suffix, which is an internal development of Albanian language. By analogy it is also spread to other nouns, which do not have -es suffix in their structure (Xhuvani, Çabej 1962)". Precisely such formations are: kënaqësi - pleasure (p.11-, No.31), shpejtësi - velocity (p.3, №.22), aftësi ability (p.3, no.22), qetësi - quietness ( $p .3$, no.22), njehësi- (p.18, no.20) mirësi - kindness ( $p .11$, no.31); shndetsi medicine; pleqsi - old age; do not have the -es in their structure. This suffix forms abstract nouns which indicate the quality features, but also the collective names as pleqsi. In the words above are joined the nominal topics (shëndet, pleq), subject adjectival the front (I afte), topics verb (kënaq, njehsoj), topics adverbial (shpejt, qetë, mirë).

Even with the predecessor of the suffix (ë)si the suffix -(ë)ri are found in this document as: mjeshtëri- the abstract noun, where the suffix -(ë)ri is attached to a topic noun which ends with a consonant, mjeshtër.

This document draws attention of the nouns which denote persons in accordance with their productive and scientific activity or in accordance with the craft they exercise or the place they reside or they stem from. They are formed with suffixes -(ë)s, -tar, -ak, -ore, as përcjellës, vartës, anëtar, llogaritar, arkëtar, ushtarak, gjykatore, ndëshkimore. While the suffix -ës is attached to the short form of past participle of the verbs përcjellë and var with the suffixes -tar, -ak, which are attached to topics, as anë -side; llogari - account; ushtar - soldier; gjykate - court; ndëshkim - punishment. More often the suffix (ës) is joined with topics of past participle of Gheg dialect with -ue or -ye. Such formations are words: kontrollues - controller; provues - tester; banues -inhabitant; zotues - commited; etc., which come from past participle verbs which end with -ue, as: kontrolloj - check; provoj - try; banoj - live; zotoj - commit.

As it is a general characteristic in Albanian language, even in the "Official Bulletin of 1925", show up a separate group formed with the suffix -isht - ly, such as the words gabimisht - incorrectly (p.-2, no.22), provizorisht - provinsionally (p.2, no.22), pjesërisht - partly (p.7, no.20), rregullisht - regularly (p.7, no.21), which belong to the class of adverb. The suffix -isht joins with nominal words, respectively gabim - incorrect, provizor - provision, pjesë - part, rregull - rule.

Even the suffix -azi has enriched Albanian vocabulary from early times. We have documented the words: ngjitazi (p.7, no.22), rishtazi (p.2, no.22), which belong to the class of adverbs of manner.

The language of the Official Bulletin of 1925 has major impacts on Gheg dialect, in morphological and formative aspects, which show the widespread use of the adjectives: të detyruem - forced; të bazuem - bazed; të dokumentuem documented; të shenjuem - signed; where Gheg suffix -uem has replaced the suffix -uar, which is widely recognized today in Albanian standard language. The same thing can be said for the use of neutral nouns like: të hymit (p.11, no.31), të marrunit (p.1, no.22), të quajtunit (p.8, no.30), të nxjerrunit (p.7, no.31) that are Gheg dialectical forms.

Special place in this text appear to have words like: shkresinë and shkresori, which are formations from the merge of a topic name shkresë with suffixes -inë and -ori. These suffixes seem to have limited use and they are not very productive in Albanian language. Thus it can be seen in individual word formations of the compilers of this document.

It is important to mention in this paper, another category of words that are formed using another productive way, composition. Such words formed by composition are: dorëheqës, kryekput, shtypshkrime, gjyqfitues, dorëheqje, aktgjykim, gjyq-bërës (p.7, No.22), post-komandë, etc.

Compound words are a very rich category in Albanian language. They are formed by the merger of two topics, which are mostly nouns and in fewer cases verbs. From nominative topic dorë+heqës is formed the word dorëheqës, from shtyp+shkrime is formed shtypshkrime, gjyq+fitues =gjyqfitues, dorë+heqje = dorëheqje, akt+gjykim = aktgjykim, 
gjyq+bërës= gjyq-bërës, post+komandë= post-komandë, where as easily seen in the two last words, the attachment process is still not completed. Meanwhile the adverb kryekput turns out to be formed by the merge of the noun krye and the verb këput.

In accordance with the lexicon and grammatical value, they are considered to be words with nominal value as: dorëheqës, shtypshkrime, gjyqfitues, dorëheqje, aktgjykim, gjyq-bërës, post-komandë, the exception is in the kryekput, which has an adverbial value.

\section{Conclusions}

As can be seen from this study the analysis of so many tools prefixes and the suffixes used from Albanian for the word formation, their demonstration in this topic, provide important data for our language grammatical formative structure in a given period of time, precisely in a period when Albanian was not a consolidated language yet. Adverbs of manner, place, time, etc., that are identified in the "Official Bulletin of 1925", clearly show that in this period was not yet completed the process of the attachment of the cluster words that make up these adverbs, as i.e.: drejt-për drejt (p.3, no.22), kur do here (p.3,no.22) nalt-përmendur ( $p .8$, no.22), për mbi ( $p .7, n o .25)$, vet-vetiut (p.6, no.22), për pos ( $\mathrm{p} .18$, no.20). They are separated and not attached as they are in the standard form of today's Albanian language, i.e drejtpërdrejt, kurdoherë, lartpërmendur, përmbi, vetvetiu, përpos, etc. It should be emphasized the adverb in dialect nalt-përmendur, which is found in the Bulletin and in standard language lartpërmendur (p.8,no.25), which shows that in this period Albanian standard language was not codified yet.

Likewise there are some indefinite pronouns as: ndo një (p.7, No.3) or ndo-nji (p.8-, No.31), which have not yet been conceived by synthetic trend of Albanian language. Written separately are also found various conjunctions, such as: veç-se (p.7, No.31), si pas (p., Nr.1-21), me qenë-se (p.7, No.25), si mbas (p.6, No. 22), etc.

\section{References}

Cipo, K., (1949) Albanian Grammar, Ndërmarrja Shtetërore e Botimeve, Tiranë,fq.39

Albanian language dictionary (1954)Institut i Shkencave,Seksioni i Gjuhës e i Letërsisë, Tirane“

Albanian language orthography dictionary (1976),Shtypshkronja Mihal Duri, Tiranë,

Dictionary of today's Albanian language (1980), Akademia E Shkencave të Shqiperise Instituti i Gjuhësise dhe i Letersise,Tiranë,

Albanian Grammar I (2002), Akademia E Shkencave të Shqiperise, Instituti i Gjuhesise dhe i Letersise,Tiranë, pg.61,63

Hysa, E., (2004), Formation of names to affix in Albanian, Instituti i Gjuhesise dhe i Letersise,Tiranë, pg.23,43

Hysa, E.,(1975)/ssues of today's albanian grammar II, Instituti i Gjuhesise dhe i Letersise,Tiranë

Hysa, E.,(1986) Studime filologjike 2, Qendra e Studimeve Albanologjike,Tiranë

Hysa, E.,(1977), Studime filologjike 4, Qendra e Studimeve Albanologjike,Tiranë

Kostallari, A.,(1972) Studies on the vocabulary of words in Albanian, I, Universiteti Shtetëror i Tiranës, Instituti i Gjuhësisë dhe i Letërsisë, Sektori i Leksikologjisë e i Leksikografisë,Tiranë,pg.68

Official Bulletin of Albanian Government in 1925

Xhuvani, A., Çabej, E.,(1962) Prapashtesat e gjuhës shqipe, Issues of today's Albanian grammar II, Instituti i Gjuhesise dhe i Letersise,Tiranë ,fq.53 